\title{
NUTRITIONAL STATUS OF CHILDREN AND ADOLESCENTS: FACTORS ASSOCIATED TO OVERWEIGHT AND FAT ACCUMULATION
}

\author{
Cristina Carpentieri Zollner Salvador ${ }^{1}$, Pedro Makumbundu Kitoko², \\ Ana Maria Dianezi Gambardella ${ }^{3}$
}

DOI: dx.doi.org/10.7322/jhdg.88969

\begin{abstract}
Objective: To estimate prevalence and identify factors associated with the nutritional status of individuals aged 8 to 17 years old in schools located at 3 administrative regions in the city of Vitória, Brazil. Methods: The nutritional status of 400 students was assessed based on a cross-sectional study. Association between overweight and fat accumulation around waist was tested considering the variables: sexual maturaten stage, income level, number of siblings, maternal Body Mass Index (BMI) and physical activity. Individuals considered stunting had height-for-age $<-2$ Z-scores of median value for the reference population; wasting, those with BMI $<5^{\text {th }}$ percentile; overweight, those with BMI $\mathrm{e}^{\prime \prime}$ 85th percentile. Waist circumference was measured under the following parameter: percentile $\mathrm{e}^{\prime \prime} 90$ of the British population. Results: Prevalence was $4.0 \%$ stunting, $4.8 \%$ wasting, $21.3 \%$ overweight and $27.3 \%$ fat accumulation around the waist. In the multiple linear model, variables associated with overweight were the following: initial and intermediate stages of sexual maturaten, maternal $B M I>25 \mathrm{~kg} / \mathrm{m}^{2}$, and high income level. Fat accumulation around the waist was associated to the following variables: maternal $B M I>25 \mathrm{~kg} / \mathrm{m}^{2}$, high income level, age $<14$, and sedentary > 28 hours/week. Conclusions: Low prevalence of nutritional deficits and high prevalence of overweight and fat accumulation around the waist were found. Higher prevalence rate occurred among individuals showing the following characteristics: higher income level; overweight mother; within initial and intermediate stages of sexual maturation; bellow 14 years old; sedentary.
\end{abstract}

Key words: nutritional status, sexual maturation, stunting, overweight, abdominal obesity, adolescent

\section{INTRODUCTION}

Adolescence is an important period for human growth and development. In this stage of life, the individual undergoes fast-paced physical and psychosocial changes, setting patterns for adult life ${ }^{1}$.

During adolescence nutritional problems coming from earlier life stages can be more easily solved. Good eating habits and healthy life style may be adopted and kept through adulthood. Therefore, monitoring adolescents' nutritional status may avoid or postpone the onset of chronic diseases in later stages ${ }^{2}$.

Population-based studies in Brazil on the nutritional status of children and adolescents address critical rises on overweight during last decades, with higher concentration of cases in individuals pursuing higher incomes. In a few
Brazilian cities, rates are similar or even higher to those in developed countries e.g., Pelotas and Santos, with $25.9 \%$ and $33.7 \%$ respectively, compared to average $31.9 \%$ in the USA. In Brazilian adult population, the rate is about $50 \%^{3-6}$.

Results are worrisome considering that obesity is an illness and also a powerful risk factor for other health problems, e.g. cardiovascular diseases, hypertension, some types of cancer, diabetes mellitus, and psychosocial disturbs. It is also associated with a rise on risk of early death ${ }^{2,7}$. Some authors have shown the type of obesity with fat accumulation around the waist is associated with higher risk of metabolic diseases?.

Obesity prevention mechanisms are required, given the difficulty to reverse it in adulthood, when changes on eating and physical activities habits are already set, besides the body's trend to maintain

\footnotetext{
1 Nutritionist at the Espírito Santo state Department of Health - Vitória/ES - Brazil - CEP 29050-625.

2 President of the Espírito Santo state Council of Food and Nutritional Security - Vitória/ES - Brazil.

3 Professor at the Faculty of Public Health, University of São Paulo - São Paulo - SP - Brazil.

Corresponding author: zollner@usp.br

Aplicação do estudo (novidade): crianças e adolescentes nos estágios de maturação sexual inicial ou intermediária são mais sedentárias e com maior sobrepeso. Nas famílias de maior renda, há maior sobrepeso e obesidade.
} 
the highest achieved weight. Nevertheless, treating obesity at this stage demands special attention, as a calorie-restricted diet may affect growth, reinforcing needs for prevention ${ }^{2,8}$.

Whereas obesity has become a public health issue and require actions for prevention and control, national survey Pesquisas de Orçamentos Familiares 2008-2009 (Survey on Families' Budgets) conducted by the Brazilian Institute of Geography and Statistics - IBGE shows a deficit value higher than expected for healthy populations (in spite of a gradual decrease on nutritional deficiencies in last decades). This happens particularly among bellow-5-year children, with higher concentration in individuals with low incomes $(8.2 \%)$ when compared to wealthier ones $(3.1 \%)^{5}$, leaving space for monitoring such deficits.

Thus, the objective is to describe the factors associated to overweight and fat accumulation in school children and adolescents.

\section{METHODS}

The study design is cross-sectional, population-based. Assessed population was composed of $4^{\text {th }}$-to- $9^{\text {th }}$ grade students from public and private Elementary Schools within three administrative regions in the city of Vitória, capital of Espírito Santo state, Brazil.

A sample of 450 students was randomly chosen from 14.734 students. Size of initial sample was determined by the formula:

$$
\mathrm{n}=\frac{\mathrm{N} \cdot \mathrm{n}_{0}}{\mathrm{~N}+\mathrm{n}_{0}}
$$

where: $\mathrm{n}=$ sample size; $\mathrm{N}=$ total individuals; $\mathrm{n}_{0}=$ first approximation to the size of obtained sample, dividing 1 by the adopted acceptable sampling error: 0.05 .

In first stage, 18 schools (12 public and 6 private) were randomly chosen out of 42 , considering the proportion of their distribution. Public and private schools were listed according to the 3 administrative regions (out of 7) selected by the Education Department of Vitória (Continental, Maruípe e Jucutuquara), in order to assure the sample's representativeness.

In second stage, students were chosen by systematic sampling on a 450-student base, 25 students per each school. 404 students were interviewed and 4 were excluded, summing 400 students in total, with $11.1 \%$ loss.

The survey used for data collection was previously tested in 2 schools, which were excluded from the sampling process.

Methods described by LOHMAN et al. ${ }^{9}$ were utilized for weight, height and waist perimeter measurement. Anthropometric measurements were done twice and median value was adopted. Interviewers were trained for standardization of the anthropometric measurements, according to the recommendations given by LOHMAN et al. ${ }^{9}$ and HABICHT et al. 9,10 .

In order to analyze anthropometric data within the studied population, height/age index and
Body Mass Index (BMI) were applied, based on reference values from the National Center for Health Statistics - NCHS, specific for each age and sex ${ }^{2}$.

Students showing stunted-growth had height/ age index 2 z-scored below the median value for the reference population; wasting those with BMI below percentile 5 and overweight those with BMI $^{3}$ percentile $85^{1}$.

Classification of waist perimeter followed parameters proposed by MCARTHY et al. ${ }^{11}$, who consider cut-points higher or equal to percentile 90 as indicative of fat accumulation around the waist ${ }^{11}$.

For classification of maternal nutritional status, BMI values proposed by WHO were chosen: low weight $<18.5 \mathrm{~kg} / \mathrm{m}^{2}$; normal weight $318,5 \mathrm{e}$ $<25 \mathrm{~kg} / \mathrm{m}^{2}$; pre-obese, obese degree I, II e III 3 $25 \mathrm{~kg} / \mathrm{m}^{2}$. ${ }^{12}$ Owing to the low frequency of lowweight mothers $(2.8 \%)$, normal-weight ones were summed.

Data on sexual maturation was provided through self-assessment by students. They were shown Tanner stages pictures without the interviewer's interference ${ }^{13}$. In case of differences between stage of pubic hair $(P)$ and breasts $(M)$ in girls, as well as pubic hair $(P)$ and genitalia $(G)$ in boys, the medium was used. For example, when P3 and $\mathrm{G} 2$ were mentioned by boys, $\mathrm{T} 2 \frac{1}{2}$ was considered instead. A variable was classified in three stages: initial ( $T 1$ and $T 1 \frac{1}{2}$ ), intermediate ( $T 2$ to $\mathrm{T}^{1} \frac{1}{2}$ ) and final (T4 to T5).

Socioeconomic information was obtained by using the National Economic Indicator (IEN), based on 12 final goods ${ }^{14}$. Values were divided in four: low income rate, low-intermediate, upperintermediate and high.

Data on physical activity was extracted from the type of sport or other kinds of physical activity practiced in the last 12 months, along with daily time practicing and week frequency. Engagement in P.E. classes and in other routine activities was also verified. Students doing physical activities for at least 5 hours a week were considered moderate or intense active ${ }^{15}$.

Data on sedentarism was calculated by summing the total time (in minutes) during which the student watched TV, played videogame or used the computer over the week. Those spending at least 28 hours doing such activities were considered sedentary ${ }^{16}$.

Dependent variables "overweight" and "fat accumulation around the waist" were analyzed, initially, by comparing frequency distribution to independent variables under study (sexual maturation, age range, sex, number of siblings, incomes, maternal BMI, physical activity and sedentarism). Then simple general linear regression was used to calculate reasons of non-adjusted prevalence for each variable.

Two models for calculating generalized linear regression (GLM) were built: first, to identify variables associated with overweight and second, to identify those associated with the fat accumulation around the waist. Multiple general linear regressions allowed assessing the effects of different variables addressing the students' nutritional status, using prevalence rate $(P R)$ to 
evaluate such effects for "overweight" and "fat accumulation around the waist".

Simple and multiple general regressions were not used for dependent variables "stunting" and "wasting" due to low found prevalence. Software Stata, 9.2 version, was employed to calculate simple generalized linear regression (SGL) and multiple generalized linear regression (MGL), binomial family with log link. For the selection of variables under study to be included in MGL in each model, it was adopted the critical level $p \leq 0.20$ of simple analysis. Variables were added to the model, once at a time, in $p$-value crescent order. In MGL, level of significance $\alpha=0.05$ was used.

The analysis of independent variables' influence on overweight considered as dependent variable: $(y)=$ BMI/age/sex (Percentile $<85=0$; Percentile $>85=1$ ) . For fat accumulation around the waist, dependent variable was $(y)=$ waist perimeter/age/sex (Percentile < $90=0$; Percentile $>90=1$ ).

This study was approved by the Committee of Ethics for Research from the Faculty of Public Health, University of São Paulo COEP (157/05), research protocol \#1339, in 29th May 2005. All the parents/people in charge of the students signed a free and clarified Consent Term.

\section{RESULTS}

In total, 400 students were interviewed, 211 boys $(52.8 \%)$ and 189 girls $(47.3 \%)$, from $4^{\text {th }}$ to $9^{\text {th }}$ grade of Elementary School of 18 schools in the city of Vitória.

Based on the adopted parameters, $4.0 \%$ of students were stunted (16 students), $4.8 \%$ had wasting (19 students), $21.3 \%$ were overweight (85 students) and $27.3 \%$ had fat accumulation around the waist (109 students).

Simple general regression analysis reveals higher prevalence of overweight among students in initial sexual maturation stage (23.3\%), younger than 12 years $(25.2 \%)$, male $(22.7 \%)$, with one siblings or none $(22.7 \%)$, doing physical activities $<5$ hours per week $(21.7 \%)$, sedentary $>28$ hours per week $(25.8 \%)$, pursuing higher incomes $(28.0 \%)$ and maternal BMI > $25 \mathrm{~kg} / \mathrm{m}^{2}(30.4 \%)$. Variables sexual maturation, age range, sedentarism, family incomes and maternal BMI had level of significance to become part of multiple general linear regression $(p \leq 0.20)$ (Table 1$)$.

Table 1: Distribution of $4^{\text {th }}$-to- $9^{\text {th }}$ grade students from public and private Elementary Schools, according to overweight and variables under study. Vitória, ES, Brazil, 2007

\begin{tabular}{|c|c|c|c|c|c|c|c|c|}
\hline \multirow{3}{*}{$\begin{array}{l}\text { Variable } \\
\text { Category }\end{array}$} & \multicolumn{3}{|c|}{ Nutritional status } & \\
\hline & \multicolumn{2}{|c|}{ BMI $<85$} & \multicolumn{2}{|l|}{ BMI $\geq 85$} & \multirow[b]{2}{*}{$\mathbf{n}$} & & Total & \multirow[b]{2}{*}{$\boldsymbol{p}$} \\
\hline & $\mathbf{n}$ & $\%$ & $\bar{n}$ & $\%$ & & $\%$ & PR & \\
\hline \multicolumn{9}{|l|}{ Sexual maturation } \\
\hline Initial & 79 & 76.7 & 24 & 23.3 & 103 & 100 & 1.89 & 0.090 \\
\hline Intermediate & 179 & 77.2 & 53 & 22.8 & 232 & 100 & 1.86 & \\
\hline Final & 57 & 87.7 & 8 & 12.3 & 65 & 100 & 1 & 0.079 \\
\hline \multicolumn{9}{|l|}{ Age range } \\
\hline $8-12$ years & 151 & 74.8 & 51 & 25.2 & 202 & 100 & 1 & \\
\hline $12-14$ years & 103 & 81.7 & 23 & 18.3 & 126 & 100 & 0.72 & 0.148 \\
\hline $14-17$ years & 61 & 84.7 & 11 & 15.3 & 72 & 100 & 0.61 & 0.097 \\
\hline \multicolumn{9}{|l|}{ Sex } \\
\hline Female & 152 & 80.4 & 37 & 19.6 & 189 & & & \\
\hline Male & 163 & 77.3 & 48 & 22.7 & 211 & 100 & 11.16 & 0.440 \\
\hline \multicolumn{9}{|l|}{ Number of siblings } \\
\hline 0 to 1 sibling & 167 & 77.3 & 49 & 22.7 & 216 & 100 & 1 & \\
\hline 2 siblings or more & 148 & 80.4 & 36 & 19.6 & 184 & 100 & 0.86 & 0.449 \\
\hline \multicolumn{9}{|l|}{ Physical activity } \\
\hline $0-5$ hours/week & 170 & 78.3 & 47 & 21.7 & 217 & 100 & 1 & \\
\hline 5 hours/week or more & 145 & 79.2 & 38 & 20.8 & 183 & 100 & 0.96 & 0.828 \\
\hline \multicolumn{9}{|l|}{ Sedentarism } \\
\hline $0-28$ hours/week & 183 & 82.4 & 39 & 17.6 & 222 & 100 & 1 & \\
\hline 28 hours/week or more & e 132 & 74.2 & 46 & 25.8 & 178 & 100 & 1.47 & 0.046 \\
\hline \multicolumn{9}{|c|}{ Incomes (IEN) } \\
\hline 10 quarter & 84 & 84,0 & 16 & 16,0 & 100 & 100 & 1 & \\
\hline 20 quarter & 82 & 82,0 & & 18 & 18,0 & 100 & 1.13 & 0.707 \\
\hline 30 quarter & 77 & 77,0 & 23 & 23,0 & 100 & 100 & 1.44 & 0.216 \\
\hline $4^{\circ}$ quarter & 72 & 72,0 & 28 & 28,0 & 100 & 100 & 1.75 & 0.045 \\
\hline \multicolumn{9}{|l|}{ Maternal BMI } \\
\hline$<25 \mathrm{~kg} / \mathrm{m}^{2}$ & 159 & 84.1 & 69.6 & 30 & 15,9 & 189 & 1 & \\
\hline$>25 \mathrm{~kg} / \mathrm{m}^{2}$ & 94 & 69,6 & 41 & 30.4 & 135 & 100 & 1.91 & 0.002 \\
\hline Total & 315 & 78.7 & 85 & 21.3 & 400 & 100 & & \\
\hline
\end{tabular}


In multiple general linear regression model, prevalence rate was higher among individuals in initial and intermediate sexual maturation stages, whose mothers had BMI $>25 \mathrm{~kg} / \mathrm{m}^{2}$ and pursuing higher incomes, for $\alpha=0.05$ (Table 2).

For fat accumulation around the waist, prevalence was higher among students in initial sexual maturation stage (28.2\%), younger than 12 years $(29.7 \%)$, female $(29.1 \%)$, with one sibling or none $(29.2 \%)$, doing physical activities $<5$ hours per week $(28.1 \%)$, sedentary $>28$ hours per week $(35.4 \%)$, pursuing higher incomes $(34.0 \%)$ and maternal BMI e" $25 \mathrm{~kg} / \mathrm{m}^{2}$ (37;8\%). Same variables in overweight had level of significance to be part of multiple general linear regression $(p \geq 0.20)$, except for sexual maturation (Table 3 ).

Table 2: Prevalence rate (PR) and overweight confidence intervals $\left(\mathrm{CI}_{95 \%}\right)$, according to the following variables: sexual maturation, maternal BMI and incomes. Vitória, ES, Brazil, 2007

\begin{tabular}{|c|c|c|c|c|}
\hline Variable & Category & Non-adjusted PR & Adjusted PR ( IC $\left._{95 \%}\right)$ & $\boldsymbol{p}$ \\
\hline Sexual & Initial & 1.89 & $2.19(1.0655-4.5052)$ & 0.033 \\
\hline maturation & Intermediate & $\begin{array}{c}1.86 \\
1\end{array}$ & $\begin{array}{c}2.13(1.0743-4.2469) \\
1\end{array}$ & 0.030 \\
\hline Maternal BMI & $\begin{array}{l}\text { Final } \\
<25 \mathrm{~kg} / \mathrm{m}^{2} \\
>25 \mathrm{~kg} / \mathrm{m}^{2}\end{array}$ & $\begin{array}{c}1 \\
1.91\end{array}$ & $2.04(1.3574-3.0872)$ & 0.001 \\
\hline Incomes (IEN) & $\begin{array}{l}10 \text { quarter } \\
2^{\circ} \text { quarter } \\
3^{\circ} \text { quarter } \\
4^{\circ} \text { quarter }\end{array}$ & $\begin{array}{l}1 \\
1.13 \\
1.44 \\
1.75\end{array}$ & $\begin{array}{c}1 \\
1.11(0.6047-2.0541) \\
1.34(0.7498-2.3847) \\
1.78(1.0257-3.0893)\end{array}$ & $\begin{array}{l}0.728 \\
0.325 \\
\mathbf{0 . 0 4 0}\end{array}$ \\
\hline
\end{tabular}

Table 3: Distribution of $4^{\text {th }}$-to- $9^{\text {th }}$ grade students from public and private Elementary Schools, according to fat accumulation around the waist and variables under study. Vitória, ES, Brazil, 2007

\begin{tabular}{|c|c|c|c|c|c|c|c|c|}
\hline \multirow{3}{*}{$\begin{array}{l}\text { Variable } \\
\text { Category }\end{array}$} & \multicolumn{4}{|c|}{ Nutritional status } & \multirow{2}{*}{\multicolumn{4}{|c|}{ Total }} \\
\hline & \multicolumn{2}{|c|}{ BMI $<85$} & \multicolumn{2}{|c|}{ BMI $\geq 85$} & & & & \\
\hline & $\mathbf{n}$ & $\%$ & $\mathbf{n}$ & $\%$ & $\mathbf{n}$ & $\%$ & PR & $\boldsymbol{p}$ \\
\hline \multicolumn{9}{|l|}{ Sexual maturaten } \\
\hline Initial & 74 & 71.8 & 29 & 28.2 & 103 & 100 & 1.15 & 0.616 \\
\hline Intermediate & 168 & 72.4 & 64 & 27.6 & 232 & 100 & 1.12 & 0.637 \\
\hline Final & 49 & 75.4 & 16 & 24.6 & 65 & 100 & 1 & \\
\hline \multicolumn{9}{|l|}{ Age range } \\
\hline $8-12$ years & 142 & 70.3 & 60 & 29.7 & 202 & 100 & 1 & \\
\hline $12-14$ years & 89 & 70.6 & 37 & 29.4 & 126 & 100 & 0.99 & 0.948 \\
\hline $14-17$ years & 60 & 83.3 & 12 & 16.7 & 72 & & 0.04 & 0.043 \\
\hline \multicolumn{9}{|l|}{ Sex } \\
\hline Female & 134 & 70.9 & 55 & 29.1 & 189 & 100 & 1 & \\
\hline Male & 157 & 74.4 & 54 & 25.6 & 211 & 100 & 0.88 & 0.432 \\
\hline \multicolumn{9}{|l|}{ Number of siblings } \\
\hline 0 to 1 sibling & 153 & 70.8 & 63 & 29.2 & 216 & 100 & 1 & \\
\hline 2 siblings or more & 138 & 75.0 & 46 & 25.0 & 184 & 100 & 0.86 & 0.353 \\
\hline \multicolumn{9}{|l|}{ Physical activity } \\
\hline $0-5$ hours/week & 156 & 71.9 & 61 & 28.1 & 217 & 100 & 1 & \\
\hline 5 hours/week or more & 135 & 73.8 & 48 & 26.2 & 183 & 100 & 0.93 & 0.674 \\
\hline \multicolumn{9}{|l|}{ Sedentarism } \\
\hline $0-28$ hours/week & 176 & 79.3 & 46 & 20.7 & 222 & 100 & 1 & \\
\hline 28 hours/week or more & 115 & 64.6 & 63 & 35.4 & 178 & 100 & 1.71 & 0.001 \\
\hline \multicolumn{9}{|l|}{ Incomes (IEN) } \\
\hline 10 quarter & 84 & 84.0 & 16 & 16.0 & 100 & 100 & 1 & \\
\hline 20 quarter & 71 & 71.0 & 29 & 29.0 & 100 & 100 & 1.81 & 0.032 \\
\hline 30 quarter & 70 & 70.0 & 30 & 30.0 & 100 & 100 & 1.88 & 0.022 \\
\hline $4^{\circ}$ quarter & 66 & 66.0 & 34 & 34.0 & 100 & 100 & 2,13 & 0.054 \\
\hline \multicolumn{9}{|l|}{ BMI maternal } \\
\hline$<25 \mathrm{~kg} / \mathrm{m}^{2}$ & 149 & 78.8 & 40 & 21.2 & 189 & 100 & 1 & \\
\hline$>25 \mathrm{~kg} / \mathrm{m}^{2}$ & 84 & 62.2 & 51 & 37.8 & 135 & 100 & 1.79 & 0.001 \\
\hline Total & 291 & 72.7 & 109 & 27.3 & 400 & 100 & & \\
\hline
\end{tabular}


In multiple general linear regression, individuals with higher incomes, sedentary and whose mothers had BMI e" $25 \mathrm{~kg} / \mathrm{m}^{2}$, had higher prevalence rate of fat accumulation around the waist and individuals over 14 years, lower prevalence rate for $\alpha=0.05$ (Table 4 ).

Table 4: Prevalence rate (PR) and confidence intervals ( $C I{ }_{95 \%}$ ) for fat accumulation around the waist, according to the variables: maternal BMI, incomes, age range e sedentarism. Vitória, ES, Brazil 2007

$\begin{array}{lcccc}\text { Variable } & \text { Category } & \text { Non-adjusted PR } & \left.\text { Adjusted PR (IC }{ }_{95 \%}\right) & p \\ \text { Maternal BMI } & <25 \mathrm{~kg} / \mathrm{m}^{2} & 1 & 1 & \mathbf{p} \\ & >25 \mathrm{~kg} / \mathrm{m}^{2} & 1.79 & 1.78(1.2683-2,5085) & \mathbf{0 . 0 0 1} \\ \text { Incomes (IEN) } & 10 \text { quarter } & 1 & 1 & 0.051 \\ & 20 \text { quarter } & 1.81 & 1.69(0.9968-2,856) & 0.111 \\ & 30 \text { quarter } & 1.88 & 1.54(0.9056-2,6227) & \mathbf{0 . 0 1 7} \\ & 40 \text { quarter } & 2,13 & 1.88(1.1120-3,1427) & \mathbf{0 . 0 0 1} \\ \text { Sedentarism } & <28 \mathrm{~h} / \mathrm{sem} & 1 & 1.70(1.2361-2,3356) & \\ \text { Age range } & >28 \mathrm{~h} / \mathrm{sem} & 1.71 & & 1 \\ & 8-12 & 1 & 0.87(0.6296-1.202) & 0.398 \\ & 12-14 & 0.99 & 0.49(0.2839-0.8330) & \mathbf{0 . 0 0 9}\end{array}$

\section{DISCUSSION}

Nutritional deficiencies are not a major problem within the assessed group. Low prevalence of stunting $(4.0 \%)$ and wasting $(4.8 \%)$ are next to the expected for a healthy population: $2.3 \%$ and $5.0 \%$ respectively. Such results corroborate population studies in Brazil showing low prevalence of nutritional deficits among children and adolescents. This rate has been decreasing over the course of last decades $2,3,5$.

Overweight and fat accumulation around the waist had high prevalence within the group: $21.3 \%$ and $27.3 \%$ respectively. Such values are above the expected for a healthy population, which are $15 \%$ and $10 \%$ respectively, according to adopted criteria. Results are not to be compared with other studies, considering different criteria employed for nutritional assessment. Nevertheless, it is unquestionable the increase on prevalence of obesity in Brazilian adolescents, overcoming nutritional deficiencies ${ }^{2-5,17,18}$.

Brazilian studies confirm higher prevalence of overweight and fat accumulation around the waist in wealthier individuals (about twice more), unlike findings in developed countries, where the opposite is verified, even among children and adolescents ${ }^{5,18-21}$

It is worth mentioning that almost one third of these individuals showed bad distribution of body fat (a risk for metabolic diseases), with prevalence of fat accumulation around the waist almost $1 / 4$ more than overweight (considering BMI percentile $>85^{\circ}$ ).

PNDS-2006 describes more disturbing results, as half of the assessed Brazilian women between 15 and 49 years had fat accumulation around the waist. In 45 to 40 years age range, frequency reached about $75 \%^{22}$.

Such findings reinforce the need for waist circumference measurement in health units as a trial for individuals under risk of metabolic diseases.
Maternal BMI was also associated to problems related to obesity. Individuals with mothers pursuing BMI e" $25 \mathrm{~kg} / \mathrm{m}^{2}$ showed prevalence rate of 2.04 times and 1.75 times for overweight and fat accumulation around the waist, when compared to students whose mothers had BMI $<25 \mathrm{~kg} / \mathrm{m}^{2}$.

Some authors confirm such results; however, there is not clear evidence that obesity is determined by genetics or environmental factors $23,24,25$. Sharing similar socio-environmental and culture backgrounds may be associated to close nutritional status between mothers and their children, although problems may appear in different periods 23,24 .

It is worth remarking that sedentarism was more strongly associated to fat accumulation around the waist than overweight. Simple analysis had this variable associated to two factors, but it did not last in multiple analyses.

Physical activity did not have level of significance for this study. This may reflect reverse causality, owing to cross-sectional approach, as obesity might have motivated individuals to start physical activities or yet because of limitations on sample collection.

Variable sedentarism measured the period in which these individuals were inactive, with reduction on energy expenditure, and probably higher consumption of food, possibly stimulated by media ${ }^{25}$. Studies show that less one hour per day (during one year) of television, video and computer may reduce $2 \%$ in prevalence of overweight ${ }^{26,27}$.

Week hours spent in sedentary activities is averagely 28 hours/week, whereas physical activities did not reach 4 hours/week, with an average of 1.8 hours/week, i.e. $50 \%$ of students practiced less than 2 hours per week of physical activities.

Considering sexual maturation, students in initial and intermediate stages had overweight 
prevalence rate about twice more than those in final stage. Such result corresponds to the literature, as adolescents in final development stage are expected to be thinner and those in stages 1 and 2 of pubertal development occasionally show an increase on body $\mathrm{BMI}^{28,29}$

Thus, we define the quality of public health at any given time must be compatible with future generations enjoying health in an equivalent way. Public health practitioners must also integrate sustain ability in the definition of public health public health measures include ensuring a safe and healthy environment, clean water, safe workplaces; promotion of healthy behaviors such as hand washing and breast feeding; and, preventing

\section{REFERENCES}

1. WHO. World Health Organization. Physical status: the use and interpretation of anthropometry. Geneva; 1995 (WHO Technical Report Series, 854).

2. WHO- World Health Organization. Nutrition in adolescence: issues and challenges for the health sector: issues in adolescent health and development [Internet]. Geneva; 2005 [acesso em 30 nov 2006]. Disponível em: http:// www.who.int/child-adolescent-health/ New_Publications/ADH/ISBN_92_4_ 159366_0.pdf.

3. Anjos LA, Castro IRR, Engstrom EM, Azevedo AMF. Crescimento e estado nutricional em amostra probabilística de escolares no Município do Rio de Janeiro, 1999. Cad Saúde Pública. 2003; 19 Supl 1:171-9. doi: 10.1590/S0102$311 \times 2003000700018$.

4. Costa RF, Cintra IP, Fisberg M. Prevalência de sobrepeso e obesidade em escolares da cidade de Santos, SP. Arq Bras Endocrinol Metab. 2006; 50 (1): 60-7. doi: 10.1590/S000427302006000100009.

5. IBGE- Instituto Brasileiro de Geografia e Estatística. Pesquisa de Orçamentos Familiares (2008-2009): Antropometria e estado nutricional de crianças, adolescentes e adultos no Brazil [Internet]. Rio de Janeiro; 2010 [acesso em 13 set 2010]. Disponível em: http:/ /www.ibge.gov.br

6. Ogden $\mathrm{CL}$, Carrol MD, Flegal KM. High body mass index for age among US children and adolescents, 2003-2006. JAMA. 2008; 299 (20): 2401-5. doi: 10.1001/jama.299.20.2401.

7. Castillo EH, Borges G, Talavera JO, Orozco R, Vargas-Alemán C, Huitrón-Bravo G, et al. Body mass index and the prevalence of metabolic syndrome among children and adolescents in two Mexican populations. J Adolesc Health. 2007; 40: 521-6. doi:10.1016/j.jadohealth. 2006.12.015.

8. Dokken BB, Tsao T. The physiology of body weight regulation: are we too efficient for our own good? Diabetes Spectrum. 2007; 20 (3): 166-70. doi: 10.2337/diaspect.20.3.166

9. Lohman TG, Roche AF, Martorrel R. Anthropometric Standardization Reference Manual. Illinois: Human Kinetics Books; 1988. infectious diseases such as delivery of vaccinations and distribution of condoms to control the spread of sexually transmitted diseases ${ }^{30}$, including reduction and variable of sedentarism.

In conclusion, low prevalence of nutritional deficiencies and high prevalence of indicators associated to obesity were found. Prevalence rate is higher in wealthier students, those whose mothers had BMI $>25 \mathrm{~kg} / \mathrm{m}^{2}$, sedentary ones, within initial or intermediate sexual maturation state, and below 14 years old.

Results follow trends observed in other Brazilian states over the course of the last decade. More studies are needed for monitoring nutritional status of adolescents in the city of Vitória.

10. Habicth JP, Martorrel R, Yarbrough C, Malina RM, Klein RE. Height and weight standard for preschool children: how relevante are ethnic differences in growth potential? Lancet. 1974; 1:611-5. doi:10.1016/S0140-6736(74)92663-4.

11. McCarthy HD, Jarrett KV, Crawley HF. The development of waist circumference percentiles in British children aged 5.0-16.9 y. Eur J Clin Nutr. 2001; 55: 902-7.

12. WHO- World Health Organization: Obesity: preventing and managing the global epidemic: report of a WHO consultation on obesity. Geneva; 1998.

13. Colli AS, Coates V, Guimarães BEM. Monitoração do crescimento e desenvolvimento físico. In: Coates V. Medicina do adolescente. São Paulo: Sarvier; 1993. p.51-65.

14. Barros AJD, Victora CG. Indicador econômico para o Brazil baseado no censo demográfico de 2000. Rev Saúde Pública. 2005; 39 (4). doi: 10.1590/S0034-89102005000400002.

15. Florindo AA, Romero A, Peres SV, Silva MV, Slater B. Desenvolvimento e validação de um questionário de avaliação de atividade física para adolescentes. Rev Saúde Pública. 2006; 40(5). doi:10.1590/S0034-89102006005000002.

16. Eisenman JC, Bartee RT, Wang MQ. Physical activity, TV viewing, and weight in U.S. youth: 1999 Youth Risk Behavior Survey. Obesity Research. 2002; 10(5): 379-85. doi: 10.1038/ oby.2002.52.

17. Garcia GCB, Gambardella AMD, Frutuoso MFP. Estado nutricional e consumo alimentar de adolescentes de um centro de juventude da cidade de São Paulo. Rev Nutr. 2003; 16(1): 41-50. doi:10.1590/S1415-52732003000100 005.

18. Oliveira CS, Veiga GV. Estado nutricional e maturação sexual de adolescentes de uma escola pública e uma escola privada do Município do Rio de janeiro. Rev Nutr. 2005; 18 (2). doi: 10.1590/S1415-52732005000200 002.

19. Okosun IS, Boltri JM, Eriksen MP, Hepburn VA. Trends in abdominal obesity in young people: United States 1988 - 2002. Ethn Dis. 2006; 16 (2): 338-44.

20. Wake M, Hardy P, Canterford L, Sawyer M, Carlin JB. Overweight, obesity and girth of Australian preschoolers: prevalence and socio-economic 
correlates. Int J Obes. 2007; 31: 1044-51. doi: 10.1038/sj.ijo.0803503.

21. Lioret S, Touvier M, Lafay L, Volatier J-L, Maire B. Dietary and physical activity patterns in French children are related to overweight and socioeconomic status. J Nutr. 2008; 138: 101-7.

22. PNDS - Pesquisa Nacional de Demografia e Saúde da criança e da mulher. Dimensão do Processo Reprodutivo e da saúde da criança [Internet]. Brasília; 2009 [acesso em 14 set 2010]. Disponível em: http://bvsms.saude. gov.br/bvs/publicacoes/pnds_crianca_ mulher.pdf

23. Ravussin E, Swinburn BA. Pathophysiology of obesity. Lancet. 1992; 340: 404-8. doi: 10.1016/0140-6736(92)91480-V.

24. Bouchard $C$. Current understanding of the etiology of obesity: genetic and nongenetic factors. Am J Clin Nutr. 1991; 53 (Supl) (6): 1561-5.

25. Novaes JF, Franceschini SC, Priore SE. Comparison of the anthropometric and biochemical variables between children and their parents. Arch Latinoam Nutr. 2007; 57 (2): $137-45$.
26. Epstein LH, Roemmich JN, Robinson JL, Paluch PA, Winiewicz DD, Fuerch JH, et al. A randomized trial of the effects of reducing television viewing and computer use on body mass index in young children. Arch Pediatr Adolesc Med 2008; 162 (3): 283-4. doi: 10.1001/archpediatrics.2007.45.

27. Wijga AH. Scholtens S, Bemelmans WI, Kerkhof M, Koppelman GH, Brunekreef B, et al. Diet, screen time, physical activity, and childhood overweight in the general population and in high risk subgroups: Prospective analysis in the PIAMA birth cohort. J obesi. 2010; 2010:1-9. doi: 10.1155/2010/423296.

28. Kanbur NO, Derman O, Kinik E. Prevalence of obesity in adolescents and the impact of sexual maturation stage on body mass index in obese adolescents. Int J Adolesc. Med Health, 2002; 14(1): 61-5.

29. Kaplowitz PB. Link between body fat and the timing of puberty. Pediatrics. 2008; 121 Supl 3: 208-17. doi: 10.1542/peds.2007-1813F.

30. Atrash HK, Carpentier R. The evolving role of public health in the delivery of health care. J. Hum. Growth Dev. 2012; 22(3): 396-399.

\section{RESUMO}

Objetivo: estimar as prevalências e identificar os fatores associados ao estado nutricional de indivíduos de 8 a 17 anos matriculados em escolas de 3 regiões administrativas do município de Vitória. Método: avaliou-se o estado nutricional de 400 alunos a partir de um estudo transversal. Testou-se a associação entre o sobrepeso e o acúmulo de gordura na cintura com as variáveis: estágio de maturação sexual, nível socioeconômico, número de irmãos, IMC materno e atividade física. Considerou-se em déficit de estatura os indivíduos com índice estatura/idade < -2 escores z do valor mediano da população de referência, em déficit de peso aqueles com Índice de Massa Corporal $(\mathrm{IMC})<$ percentil 5 e com sobrepeso IMC e" percentil 85. Para o perímetro da cintura, adotou-se como parâmetro o percentil e" 90 da população britânica. Resultados: encontrou-se prevalência de $4,0 \%$ de déficit de estatura, 4,8\% de déficit de peso, $21,3 \%$ de sobrepeso e $27,3 \%$ de acúmulo de gordura na cintura. No modelo de regressão linear múltipla as variáveis associadas ao sobrepeso foram maturação sexual em estágio inicial e intermediário, IMC materno e" $25 \mathrm{~kg} / \mathrm{m}^{2} \mathrm{e}$ maior renda. Para acúmulo de gordura na cintura as variáveis associadas foram IMC materno e"25kg/m², maior renda, menores de 14 anos e sedentarismo e"28 horas/semana. Conclusões: observou-se baixa prevalência de déficit nutricional e elevada de sobrepeso e acúmulo de gordura na cintura, apresentando maior razão de prevalência entre os indivíduos com maior renda, com mães que apresentaram sobrepeso, nos estágios de maturação sexual inicial ou intermediária, menores de 14 anos e sedentários.

Palavras-chave: estado nutricional, maturação sexual, déficit de estatura, sobrepeso, obesidade abdominal, adolescente. 